\title{
Swirling flame combustion of heavy fuel oil: Effect of fuel sulfur content
}

\author{
Xinyan Pei a , Abdul Gani Abdul Jameel ${ }^{\text {b* }}$, Chaoqin Chen ${ }^{\text {c }}$, Ibrahim A. AlGhamdi ${ }^{\mathrm{d}}$, \\ Kamal AlAhmadi ${ }^{\mathrm{d}}$, Eid AlBarakati ${ }^{\mathrm{d}}$, Saumitra Saxena ${ }^{\mathrm{c}}{ }^{*}$ and William L. Roberts ${ }^{\mathrm{c}}$ \\ ${ }^{\text {a }}$ Institute for Aero Engine, Tsinghua University, Beijing, 100084 China \\ ${ }^{\mathrm{b}}$ Department of Chemical Engineering, King Fahd University of Petroleum \& Minerals, Dhahran 31261, \\ Saudi Arabia \\ ${ }^{\mathrm{c}}$ King Abdullah University of Science and Technology, Clean Combustion Research Center, Thuwal 23955, \\ Saudi Arabia \\ ${ }^{\mathrm{d}}$ Research and Development, Saudi Electricity Company, Riyadh 11416, Saudi Arabia \\ *Corresponding author: \\ Abdul Gani Abdul Jameel < a.abduljameel@kfupm.edu.sa > \\ Saumitra Saxena < saumitra.saxena@kaust.edu.sa >
}

\begin{abstract}
In the present work, an experimental investigation on the effect of sulfur content in heavy fuel oil (HFO) on the gaseous emissions under swirling flame conditions was carried out. The sulfur content in HFO was varied by blending with ultra-low sulfur diesel and four fuel samples containing 3.15, 2.80, 1.97 and $0.52 \%$ sulfur (by mass) were prepared. Pure asphaltenes were added to the blends to ensure that the asphaltene content in the fuel remained the same. The fuels were then fired in a highswirl stabilized, turbulent spray flame. The combustion performance of the fuels was evaluated by measuring flame temperature distribution, gaseous emissions $\left(\mathrm{SO}_{\mathrm{x}}, \mathrm{NO}_{\mathrm{x}}, \mathrm{CO}, \mathrm{CO}_{2}\right.$, and flue gas $\left.\mathrm{pH}\right)$ and particulate matter (PM) emissions (morphology, composition, and $\mathrm{pH}$ ). The results showed a significant reduction in the $\mathrm{SO}_{2}$ emissions and acidity of the flue gas when the sulfur content in the fuel was reduced, as expected. The reduction was more than would be expected based on sulfur content however. For example, the flue gas $\mathrm{SO}_{2}$ concentration reduced from $620 \mathrm{ppm}$ to $48 \mathrm{ppm}$ when the sulfur content in the fuel was reduced from 3.15 to $0.52 \%$ (by mass). Sulfur balance calculations indicate that nearly $97.5 \%$ of the sulfur in the fuel translates into gaseous emissions and the remaining $2.5 \%$ appears in PM emissions. Ninety-five percent of the gaseous sulfur emissions are $\mathrm{SO}_{2}$, whereas the rest appears as $\mathrm{SO}_{3}$. Varying the sulfur content in the fuel did not have a major impact on the flame temperature distribution or $\mathrm{NO}_{\mathrm{x}}$ emissions. The morphologies and the size distribution of the PM also did not change significantly with the sulfur content as the asphaltenes content of the fuels remained the same.
\end{abstract}

Keywords: heavy fuel oil, swirl flame; sulfur emissions; particulate matter; 


\section{Introduction}

Heavy fuel oil (HFO) also called as Bunker $\mathrm{C}$ oil is an economically attractive, tar-like, lowgrade fuel used for propelling marine engines, firing industrial blast furnaces and in utility boilers for electricity generation because of its low cost, availability and high energy density. HFO is characterized by its high viscosity, high molecular weight, high asphaltenes content and complex compositional diversity possessing several thousands of individual molecules and functional groups [1-6]. HFO is rich in polycyclic sulfur aromatic hydrocarbons (PASH) [7] and also contain heavy metals like Vanadium, Nickel etc. that corrode the metal components in engines/gas turbines. Refineries usually make HFO by blending residual components from the bottom of the barrel (vacuum residues) with cutter stocks to better the flow properties. HFO usage as a fuel has been a source of debate for decades. The arguments favoring their use are centered on the utilization of a cheap energy resource whereas the counter arguments highlight the environmental hazards arising due to the notorious gaseous emissions from HFO combustion. A significant drawback of HFO stems from the large quantities of sulfur content (2-5 wt \% ) [8] present in it which results in $\mathrm{SO}_{\mathrm{x}}$ emissions when burnt [9]. These gases possess an unpleasant odor, are respiratory irritants that damage the mucus linings and lead to environmental issues like acid rain. The $\mathrm{SO}_{2}$ gas produced during HFO combustion leads to $\mathrm{SO}_{3}$ formation on subsequent oxidation and if the exhaust temperatures are lower than the dew point of the acid formed from $\mathrm{SO}_{3}$ (sulfuric acid), cold end corrosion occurs [10]. Asphaltenes present in HFO tend to reduce the combustion efficiency and cause the emissions particulate matter (PM) which are another source of concern associated with HFO usage [11]. PM emissions are the result of incomplete fuel combustion and constitute complex organic and inorganic compounds. Soot, the inorganic carbonaceous particles visualized by the emanating smoke represents more than $50 \%$ of the PM emissions and are known to be carcinogenic. Oxygenates like methanol, ethanol, dimethyl ether etc. have been blended with HFO to reduce the PM emissions [12,13]. HFO combustion also results in the inevitable release of other pollutant gases like $\mathrm{CO}, \mathrm{CO}_{2}$ and $\mathrm{NO}_{\mathrm{x}}$ which are characteristic emissions of all fossil fuel combustion. 
Due to the sulfur and PM emissions arising with HFO combustion, the International Maritime Organization (IMO) which regulates maritime shipping has restricted the sulfur content in HFO to 0.5 wt $\%$ (in open seas) to be implemented worldwide from January $1^{\text {st }}, 2020$ [14-17]. This is in addition to the $0.1 \mathrm{wt} \%$ sulfur limit already placed for ships sailing in emission controlled areas [15]. In 2011, the IMO banned the use of HFO by ships traversing the Antarctic waters due to the PM emissions that were harming the ecosystem [18,19]. An outcome of IMO 2020 legislation is that more high sulfur HFO will be channeled for power generation sector. A concerted effort is needed to improve combustion efficiency and reduce emissions from HFO combustion. The IMO 2020 sulfur regulations have led to a high demand of low sulfur marine fuels in the maritime sector. Refineries and blenders are trying to cash in this demand by blending HFO with distillate fuels like gas-oils which seems as the easiest option to produce low sulfur marine fuels, as heavy fuel desulfurization technologies are capital intensive and technically challenging [20].

Fundamental research on HFO combustion reported in the literature has mostly been carried out using suspended [21-25] and falling droplet [25-28] techniques, beside numerical modeling [2935]. These droplet experiments are unable to reproduce the spray properties seen in combustors, whereas large scale industrial furnaces on the other hand lack the experimental accuracy such that meaningful interpretation of the combustion processes can be made. There have been a limited number of turbulent spray combustion studies of HFO reported in the literature due to the difficulties in handling HFO and the high costs associated with infrastructure, operation and safety. Costa et al. [36] examined the effect of the HFO spray quality using a twin fluid atomizer on the combustion measurements i.e. gas temperatures and species concentrations namely $\mathrm{O}_{2}, \mathrm{CO}_{2}, \mathrm{CO}$ and unburnt hydrocarbons. In a follow up study, Costa et al. [37], reported the wall radiation flux, $\mathrm{NO}_{\mathrm{x}}$ and $\mathrm{PM}$ emissions and concluded that an increase in the secondary air swirl lead to better mixing and droplet vaporization which in turn resulted in lower $\mathrm{NO}_{\mathrm{x}}$ levels at the exit. Increasing the excess air from 15 to $25 \%$ resulted in better combustion near the burner region, low thermal efficiency and increased $\mathrm{NO}_{\mathrm{x}}$ emissions. Byrnes et al. [38] extended the data reported by Costa et al. [36,37] by using a rotary cup atomizer to generate HFO spray flames and measured the flame temperature along with the gas 
emissions $\left(\mathrm{O}_{2}, \mathrm{CO}, \mathrm{CO}_{2}, \mathrm{NO}_{\mathrm{x}}\right.$ and $\left.\mathrm{PM}\right)$ under a wider range of operating conditions such as swirl numbers, primary air to fuel ratios and atomizer cup speeds. Villasenor et al. [39] experimentally measured the effect of perpendicular secondary air jets on HFO flames in a cylindrical 500kW furnace by directing the secondary air jets close to the edge of the initial combustion stage and found $70 \%$ reduction in $\mathrm{NO}$ and $100 \%$ reduction in $\mathrm{CO}$. A recent study by Zeng et al. [12] investigated the effects of ultrasonic waves and magnetization on the combustion and emission performance of HFO in a twostroke diesel engine and found that the engine fuel consumption rate decreased by $1.5 \% \cdot \mathrm{CO}_{2}$ and $\mathrm{CO}$ emissions reduced while NO emissions increased slightly due to the fuel's online exposure to ultrasonic waves and magnetization effects. However, these comprehensive studies on residual HFO spray combustion do not provide insight on the effect of fuel sulfur content on gaseous emissions or temperature profile. Studies $[40,41]$ that investigate the effect of sulfur in distillate fuels like gasoline, diesel etc. on emissions have been reported extensively in the literature. In the present work, spray combustion of HFO was carried out using a high swirl, turbulent jet flame by using a novel burner design. Due to the high residual content, HFO has a significant quantity of asphaltenes and resins that make it difficult to burn $[9,21,42]$ and this requires longer residence times and higher temperatures for better combustion. The high swirl, turbulent jet flame produced by the burner results in a stabilized flame that can efficiently burn HFO by providing a long residence time and good mixing between fuel and air. The dominate effect imparted by the swirling motion of air is the improvement in the stabilization of flame due to the formation of a recirculation zone and reduction in combustion length.

The objective of the present work is to study the effect of varying the sulfur content in HFO and studying its impact on the gaseous emissions namely $\mathrm{SO}_{\mathrm{x}}, \mathrm{NO}_{\mathrm{x}}, \mathrm{CO}, \mathrm{CO}_{2}$, and their $\mathrm{pH}$. The $\mathrm{PM}$ emissions were also analyzed by studying their morphology, composition and $\mathrm{pH}$. Experimental measurements of the flame temperature distribution along the center of the flame height were also performed.

\section{Experimental methods}

The sulfur content in HFO was varied by blending it with ultra-low sulfur diesel and a total of four fuels containing $3.15 \% \mathrm{~S}$ (case 1), $2.80 \% \mathrm{~S}$ (case 2), $1.97 \% \mathrm{~S}$ (case 3) and $0.52 \% \mathrm{~S}$ (case 4) by 
mass, were prepared. Experiments were also performed using the ultra-low sulfur diesel (0\% S, case $5)$ as a reference case. The quantity of ultra-low sulfur diesel and its aromaticity $(\approx 35 \%)$ [43] was sufficiently large enough to dissolve the asphaltenes and a homogenous, visibly well mixed mixture was observed. The composition of the fuel blends are presented in Table 1. Separately obtained asphaltenes (Chinese Standard No. 90 Asphaltenes) whose properties are similar to those extracted from HFO [4] were added to the blends to ensure that the asphaltene content of the samples was similar ( $8 \%$ by mass). A few of the important physical and chemical properties of the tested fuels were experimentally measured and are presented in Table 2. The pure HFO sample had a sulfur content of $3.15 \%$ (by mass) and a gross calorific value of $42.75 \mathrm{MJ} / \mathrm{kg}$. Addition of the ultra-low sulfur diesel (ULSD) to HFO resulted in the increase of the gross calorific value whereas the heating value decreased due to the fall in density of the blend. It is noteworthy to mention that there was a marked reduction in viscosity due to the addition of the diesel.

\section{Table 1}

Composition of the fuel samples.

\begin{tabular}{|c|c|c|c|c|c|c|}
\hline \multirow[t]{2}{*}{ Name } & \multicolumn{3}{|c|}{ Composition (mass \%) } & \multirow{2}{*}{$\begin{array}{c}\text { Net } \\
\text { asphaltenes } \\
(\text { mass \%) }\end{array}$} & \multirow{2}{*}{$\begin{array}{c}\text { Sulfur } \\
\text { content } \\
(\text { mass \%) }\end{array}$} & \multirow{2}{*}{$\begin{array}{c}\text { Equivalence } \\
\text { ratio } \\
(\phi)\end{array}$} \\
\hline & HFO & Diesel & Asphaltenes & & & \\
\hline Case1 & 100 & 0 & 0 & 8 & 3.15 & 0.91 \\
\hline Case2 & 73.4 & 23.5 & 2.1 & 8 & 2.80 & 0.89 \\
\hline Case3 & 47.9 & 47.9 & 4.2 & 8 & 1.97 & 0.85 \\
\hline Case4 & 0 & 92 & 8 & 8 & 0.52 & 0.84 \\
\hline Case 5 & 0 & 100 & 0 & 0 & 0 & 0.83 \\
\hline
\end{tabular}

\section{Table 2}

Properties of the fuel samples

\begin{tabular}{lccccc}
\hline Name & $\begin{array}{c}\text { Gross } \\
\text { calorific } \\
\text { value } \\
(\mathrm{MJ} / \mathrm{kg})\end{array}$ & $\begin{array}{c}\text { Viscosity } \\
\text { at } 40^{\circ} \mathrm{C} \\
(\mathrm{mPa} . \mathrm{s})\end{array}$ & $\begin{array}{c}\text { Density at } \\
15^{\circ} \mathrm{C}(\mathrm{g} / \mathrm{ml})\end{array}$ & $\begin{array}{c}\text { Heat value } \\
(\mathrm{MJ} / \mathrm{L})\end{array}$ & $\begin{array}{c}\mathrm{H} / \mathrm{C} \text { ratio } \\
\text { (in mole })\end{array}$ \\
\hline Case1 & 42.75 & 431 & 0.97 & 41.47 & 1.58 \\
Case2 & 44.15 & 78 & 0.95 & 41.94 & 1.55 \\
Case3 & 44.84 & 17 & 0.9 & 40.36 & 1.57 \\
Case4 & 45.11 & 6.5 & 0.86 & 38.80 & 1.80 \\
Case5 & 46.08 & 2 & 0.84 & 38.70 & 1.83 \\
\hline
\end{tabular}


The schematic of the swirling flame experimental setup (shown in Figure 1) can be divided into the fuel supply system and the swirling flame combustion system. The fuel is sucked into high pressure steel cylinders (heated at $90^{\circ} \mathrm{C}$ ) using a vacuum line and from where the fuel is transferred to a heated $\left(130{ }^{\circ} \mathrm{C}\right)$ syringe pump (Harvard PHD ULTRA 4400). The pump then delivers the fuel to the burner at a constant volumetric flowrate. The swirl burner used in this work is based on the designs of Feikema et al. [44] and Chen et al. [45]. The burner is contained in a swirl generator in which air enters tangentially and axially to induce a swirling air jet. An insulated combustion chamber is applied to confine the flame above the nozzle. Figure 2 shows the burner features with two air inlets oriented to allow for the control of the swirl number independently of the equivalence ratio. The first air inlet is oriented axially and enters through the bottom of the plenum. Oriented tangentially to the walls of the plenum and perpendicularly to the axial air inlet are four additional inlets that impart the swirling momentum. Located axially along the centerline of the burner is a fuel tube. This fuel tube extends up through the mixing plenum into a venturi and quarl, whereas the exit of the tube is aligned with the base of the diverging quarl. Commercially available air atomizing nozzles from Siphon were used throughout this study, allowing for a low-pressure solution to the atomization of the viscous fuel. 


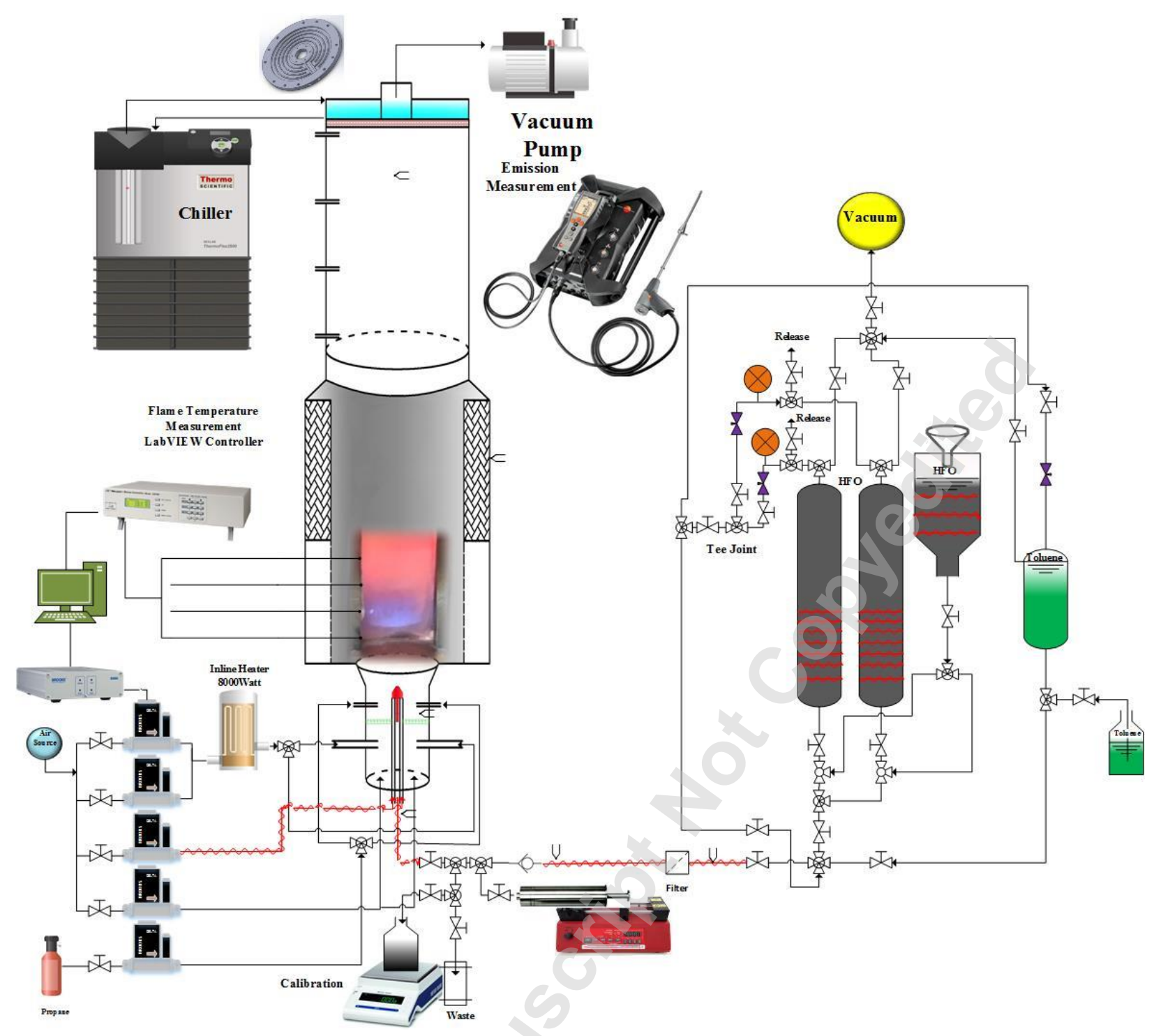

Figure 1. Schematic of the swirl spray flame combustion of HFO.
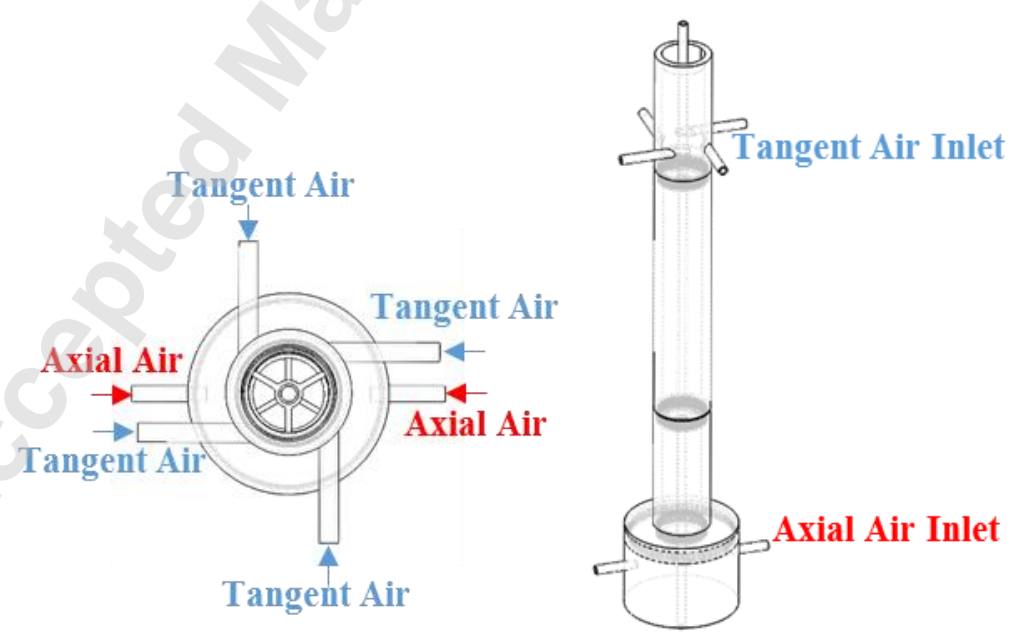

Figure 2. Swirling flow generator

Due to the difficulty in burning HFO because of its high viscosity and high auto-ignition temperature [46], a warm-up process was be followed. During the start-up, a gaseous flame was 
established with propane and maintained for 30 minutes in order to allow for the combustion chamber to reach a steady temperature. When ready to switch to liquid spray flames, the flow rate of liquid fuel was increased while simultaneously reducing the flow rate of propane. This process allows for a relatively constant energy flux and for the injection of the difficult to burn fuels (like HFO) directly into an existing flame. A quartz window fixed on the wall of the burner was used to observe the flame during the experiment. As soon as a steady HFO flame was formed, measurement of flame temperature field and gaseous emissions were conducted. An R-type thermocouple rake containing 6 thermocouples $\left(1.5^{\circ} \mathrm{C}\right.$ or $\pm 0.25 \%$ tolerance value $)$ measured the in-flame temperature along the central axis of the flame. The tip of the Pt based thermocouples covered by ceramic tubes were automatically and periodically inserted (using a LabVIEW controller) in to the center-line of the flame and the reported values are average of 4-5 readings. The in-flame temperature was measured once every 4-5 minutes and the HFO flame was kept on for a minimum duration of 25-30 minutes for every test run. The exhaust gas was allowed to pass through a microfiber filter paper (Whatman ${ }^{\mathrm{TM}}$ BinderFree Glass Microfiber) with pore size of $2.7 \mu \mathrm{m}$ where the PM emissions were collected for later analysis. The filter paper was placed on a thick circular metal plate cooled by chilled water to ensure the filter paper did not burn due to the heat of the flue gases. The experimental conditions for fuel and air are shown in Table 3. The equivalence ratio for all experimental conditions were calculated based on the elemental analysis of the fuels which were measured using an Agilent 5110 ICP-OES and Flash 2000 Organic Elemental CHNS/O Analyzer and the values are presented in Table 1.

\section{Table 3}

Experimental conditions

\begin{tabular}{ccccc}
\hline & $\begin{array}{c}\text { Tangent } \\
\text { air }\end{array}$ & $\begin{array}{c}\text { Atomizing } \\
\text { air }\end{array}$ & Axial air & $\begin{array}{c}\text { Fuel } \\
\text { flowrate }\end{array}$ \\
\hline Flow rate $(\mathrm{SLPM})$ & 150 & 15 & 5 & $15^{\mathrm{a}}$ \\
Temperature $\left({ }^{\circ} \mathrm{C}\right)$ & 600 & 150 & 300 & 150 \\
Swirling Number $\left(\mathrm{S}_{\mathrm{g}}\right)$ & & \multicolumn{2}{c}{19.2} & \\
${ }^{a}$ The fuel flowrate is in $\mathrm{ml} / \mathrm{min}$. & & \multicolumn{4}{c}{}
\end{tabular}

\section{Results \& Discussion}

\subsection{Temperature Distribution}


The in-flame temperature distribution along the central axis of the flame was measured and the values are reported in Figure 3. The large swirl number generates a strong internal recirculation zone and the combination with a possible external recirculation zone created due to the flow separation at the quarl exit, has a stabilizing effect on the HFO flame. The primary air which contains the HFO droplets penetrates the internal recirculation zone as it is directly introduced into it with a high momentum. The droplets mix with the hot re-circulated gases and undergo rapid vaporization, pyrolysis and oxidation one after the other. This results in heat release and the increase in temperature. The differences in the flame temperature profiles measured can be ascribed to changes in the global and local equivalence ratios. The flow rates of the oxidizer (air) and fuel were held constant for all the experiments. However, as the composition of the fuel blend changes, this induces a slightly different equivalence ratio. The maximum flame temperature recorded was $1200^{\circ} \mathrm{C}$ corresponding to case 2 at the axial distance equal to $50 \mathrm{~mm}$ and $95 \mathrm{~mm}$ on the centerline of the flame. The lower temperature profile for case 4 and case 5 compared to case 1 (pure HFO) is due to the lower energy density of the blended diesel. The average flame temperature calculated for each fuel (shown in Figure 4) corresponds to the heating value of the fuel reported in Table 2. The average flame temperature for cases 4 and 5 are also lower than that of case 2 . The temperatures measured near the inlet and outlet were not used for calculating the average. The variance in flame temperatures recorded here are due to the changes in the equivalence ratios and fuel energy densities. This shows that the sulfur content of the fuel does not seem to have a direct impact on the magnitude of the flame temperatures measured because sulfur does little to affect the rate of oxidation of the alkyl groups in the fuel [47]. It is noteworthy to indicate the HFO flame temperatures reported here are lower compared to others $[38,48]$ due to radiation losses. 


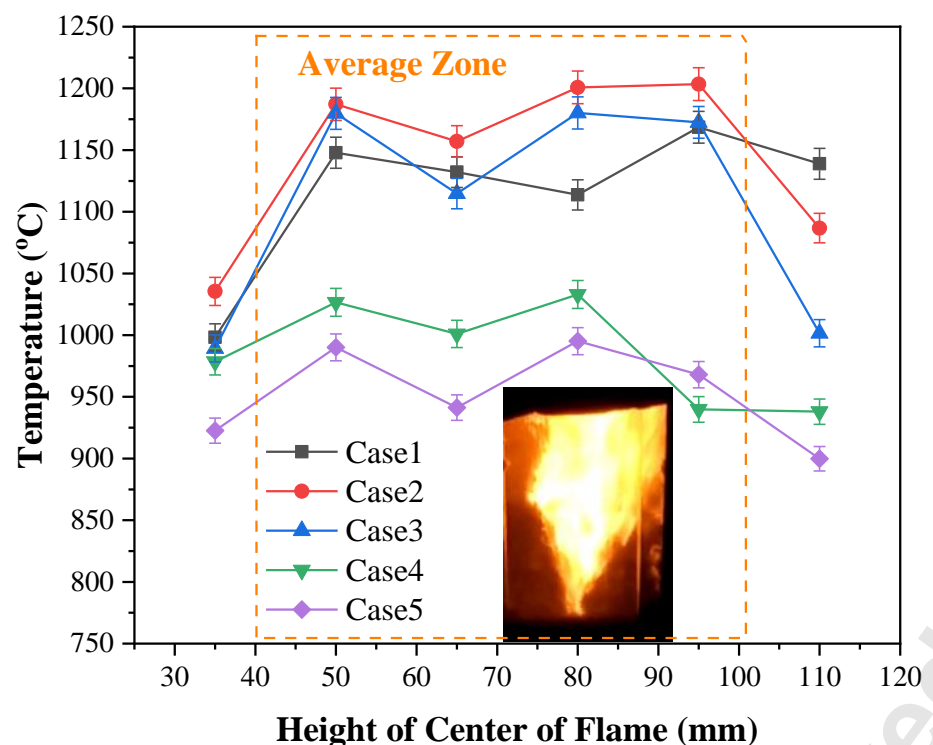

Figure 3. In-flame temperature measurements on the center line of the flame.

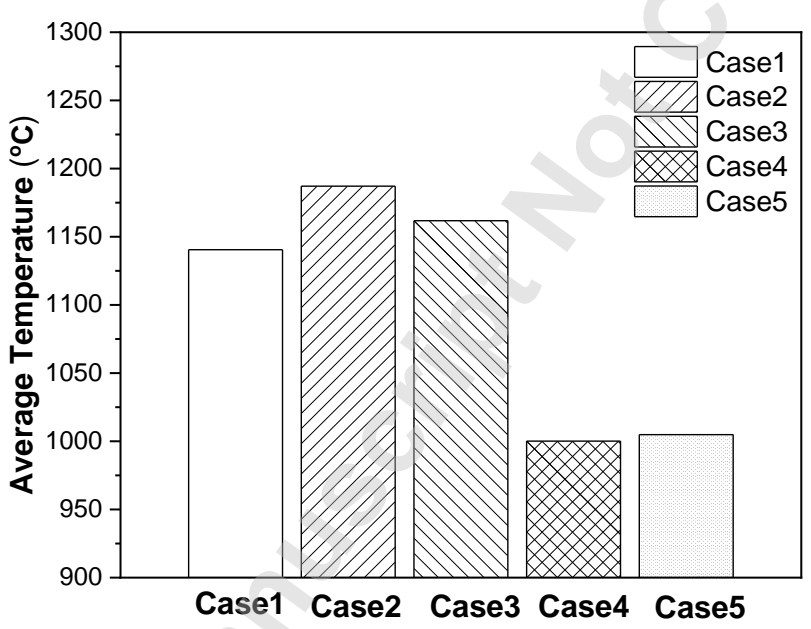

Figure 4. Average flame temperature measurements

\subsection{Gaseous emissions}

The gaseous emissions were measured by a TESTO 350 flue gas analyzer. The initial region of the flame is characterized by rapid evaporation and combustion where there is a sharp fall in $\mathrm{O}_{2}$ and hydrocarbon concentrations. Gas temperature increases following the evaporation of the droplets along with $\mathrm{CO}_{2}$ and $\mathrm{CO}$ concentration. The outer region of the flame is characterized by rising $\mathrm{O}_{2}$ concentrations due to mixing with the gases. The flue gas probe was inserted above the combustion chamber (approximately $50 \mathrm{~mm}$ above the tip of the flame) and the readings were recorded. The concentration of the pollutant gaseous emissions measured for the various cases are presented in Figure 
5. The values measured were adjusted to account for the effect of air dilution by using the following equation: $\mathrm{C}=\mathrm{C}(20.9-15) /\left(20.9-\% \mathrm{O}_{2}\right) . \mathrm{C}$ is the concentration of the emission measured and an oxygen dilution of $15 \%$ was used.

The measured $\mathrm{SO}_{2}$ emissions correlate linearly with the sulfur content and increase with increasing sulfur content in the fuel as shown by a number of studies [47,49-51]. An $\mathrm{SO}_{2}$ concentration of $620 \mathrm{ppm}$ was measured for case $1(3.15 \% \mathrm{~S})$ and $48 \mathrm{ppm}$ was measured for case 4 $(0.52 \% \mathrm{~S})$. This showed that when sulfur in the fuel was increased by 6.05 times $(3.15 / 0.52)$ then the concentration of $\mathrm{SO}_{2}$ in the flue gas increased by two folds $(620 / 48=12.9)$. Lin et al.[47] also showed doubling of $\mathrm{SO}_{2}$ concentrations measured in the flue gas of an industrial furnace when the sulfur content in the fuel was only increased from 0.3 to $1 \mathrm{wt} \%$. Varying the sulfur content did not produce a significant change in the $\mathrm{NO}_{\mathrm{x}}$ emissions which are at the same levels around $100 \mathrm{ppm}$ for cases 1,2 and 3, and correspond with the flame temperature distribution reported in Figures. 3 and 4, as NOx emissions primarly depend on the temperature of the flame zones owing to the thermal NO mechanism [52]. The concentration of $\mathrm{CO}$ fell steadily with fall in the sulfur content (from case 1 to 5) and these results follow closely with the observations by Koehl et al. [53] which indicates that $\mathrm{CO}$ formation is promoted by the sulfur content in the fuel. The higher value of CO concentration observed for case 3 deviates this trend and this could be attributed due to the varying equilance ratios in Table 1 . In the present study a high swirl number was utlized for obtaining a steady flame and a high swril number has shown to reduce the formation of $\mathrm{NOx}$ and $\mathrm{CO}[54]$ as observed in a lean pre-mixed prevaporized combustor. Also, the fuel injector used can promote or suppress self-excited oscillations which have been shown to reduce $\mathrm{NOx}$ and $\mathrm{CO}$ emissions. The $\mathrm{CO}$ formation measured in the five cases follows closely with the average flame temperature values measured (except for case 3). In all conditions, the amount of $\mathrm{CO}$ produced was insignificant in comparison to the concentration of $\mathrm{CO}_{2}$, which indicates a good combustion efficiency of HFO in the swirling flame (see section 3.4). The differences in the $\mathrm{CO}_{2}$ emissions measured can also be ascribed to the different fuel compositions and the global equivalence ratio of the fuels. Therefore, for better analysis, the gas emission results were normalized by the $\mathrm{H} / \mathrm{C}$ ratio (see Table 2) and shown in Figure 6 . It can now be seen that the $\mathrm{CO}_{2}$ concentration 
falls steadily with the fall in the sulfur content of the fuel. These results are in line with those reported by Lin et al. [47] where increasing the sulfur content of the fuel reduces the $\mathrm{CO}_{2}$ concentration and combustion efficiency.

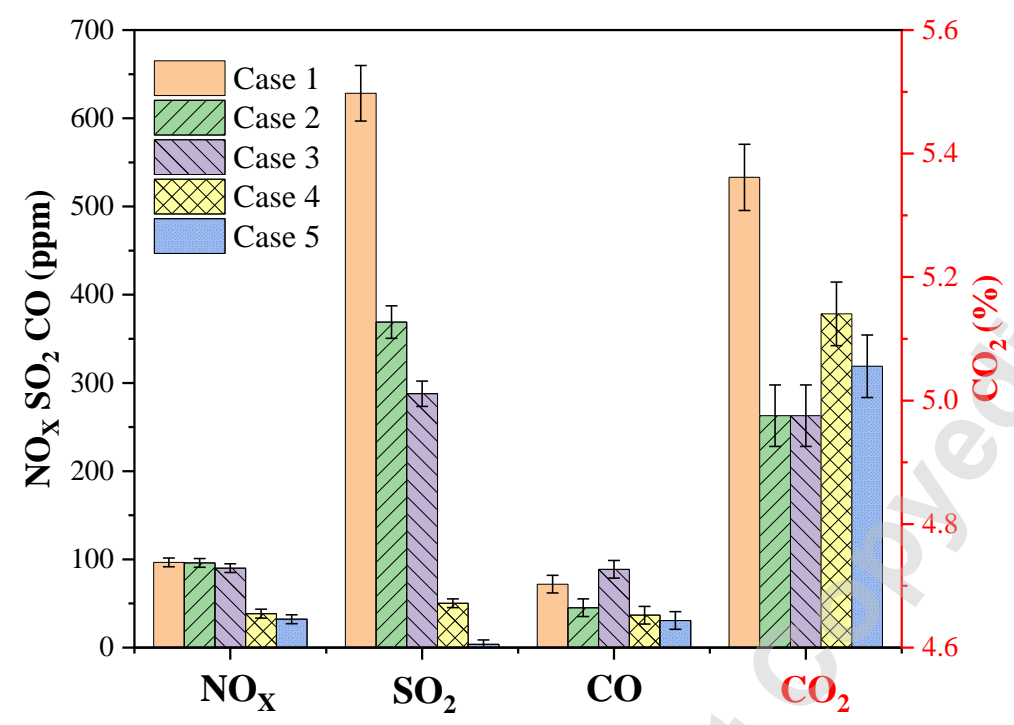

Figure 5. Concentration of the gaseous emissions

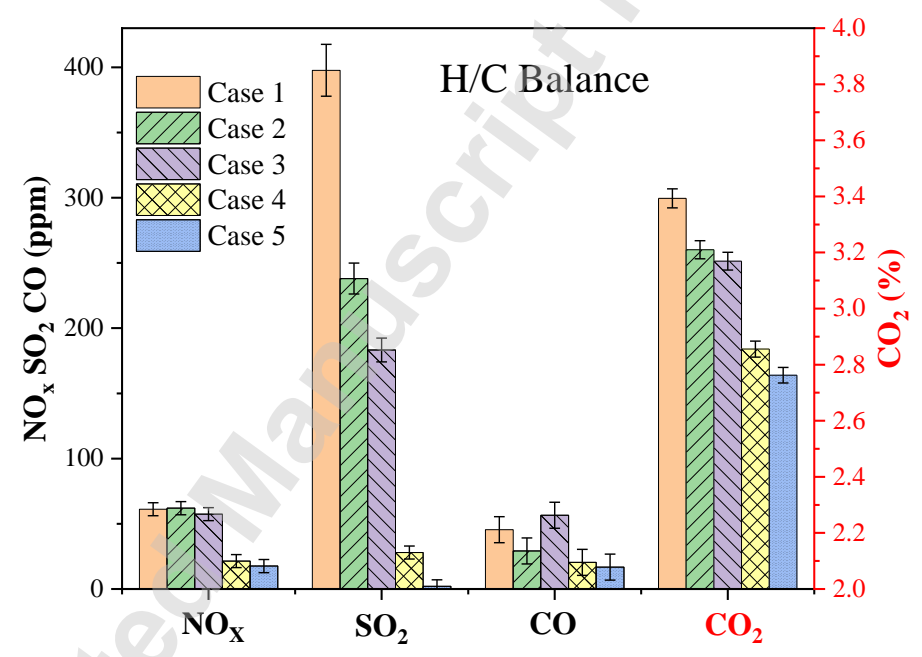

Figure 6. Concentration of the gaseous emissions normalized by $\mathrm{H} / \mathrm{C}$ ratio

The cooled flue gas emissions were dissolved in $1200 \mathrm{ml}$ of deionized water for 10 minutes and then the $\mathrm{pH}$ of the solution was measured by an Accumet AB150 pH meter immediately. The dissolution of $\mathrm{SO}_{3}$ from the flue gas increases the acidity ( $\mathrm{pH}$ reduces) of the measured solution by the formation of sulfuric acid [55]. Similarly, $\mathrm{CO}_{2}$ and $\mathrm{CO}$ dissolution may also result in the formation of carbonic acids that increase the acidity. The $\mathrm{pH}$ values measured for the various cases are presented in Figure 7. The flue gas from Case $1(3.15 \% \mathrm{~S})$ has the highest acidity levels and the flue gas from case $5(0 \%$ 
$\mathrm{S}$ ) has the lowest acidity (highest $\mathrm{pH}$ of 4.23) as expected, indicating that $\mathrm{SO}_{3}$ formation increases with fuel sulfur content

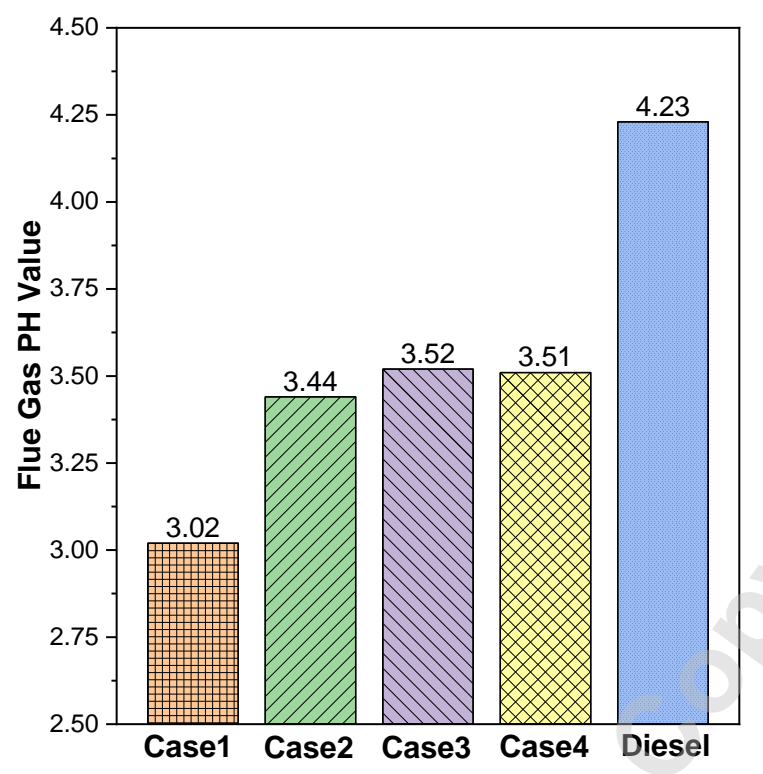

Figure 7. $\mathrm{pH}$ measurements of the flue gas

\subsection{PM emissions}

The PM collected on the microfiber filter paper was carefully scraped from the surface and used for further analysis. Scanning electron microscopy (SEM) images of the PM are shown in Figure 8, which were measured by Quanta 600 FEG device. PM of various types namely, carbonaceous and porous morphologies (type A [56]), hollow globules with bubbles in the interior and absent blowholes on the surface (type B [28]) and few perfectly smooth spherical particles (type C [26]) with diameters around 2-10 $\mu \mathrm{m}$ were observed in all four cases (PM from case 5, pure diesel was not analyzed). The morphologies of the PM formed depends on the thermal history of the fuel droplets [23,41]. There are more holes distributed on the surface of the PM from case 2 and 3 due to the combustion of light components and low boiling volatiles. In cases 1 and 4, there is more ash distributed on the background of the PM. The size distribution of the PM obtained from cases 2 and 3 were slightly bigger than those obtained from cases 1 and 4 . This indicates that the sulfur content may not play a role in the size of PM formed during combustion of heavy fuels. This, however is contrary to the results published in the literature [57-59] which indicate that lowering sulfur levels in distillate fuels results in lower PM levels. This is because in the present study asphaltenes were added externally (to cases 2, 3 and 4) to ensure 
their levels remain the same $(8 \%)$ throughout and that the results obtained were a function of fuel sulfur content only. It is well established in the literature that asphaltenes content in the fuel leads to increased PM levels [23,26,60,61]. For distillates fuels however, sulfur content has shown to impact the size and morphology of the PM formed whereas the results from the present study show that this is not the case for residual fuels where sulfur content may not have a significant impact. The compositions of the PM were measured by inductively coupled plasma - optical emission spectroscopy (ICP-OES, Agilent 5110) and Flash 2000 organic elemental CHNS/O analyzer and are presented in Table 4. The sulfur content in all the PM increased with the sulfur content in the fuel, as also shown by other studies $[59,61,62]$.

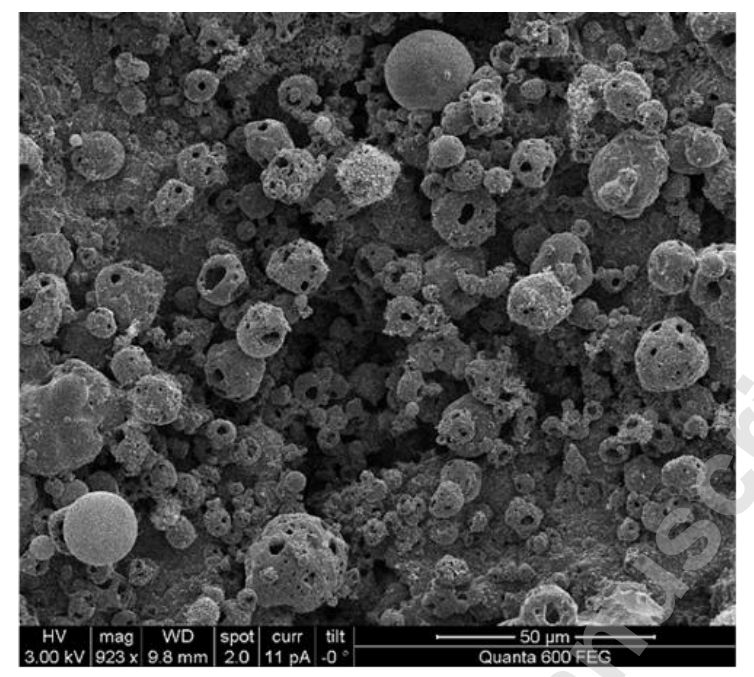

Case 1

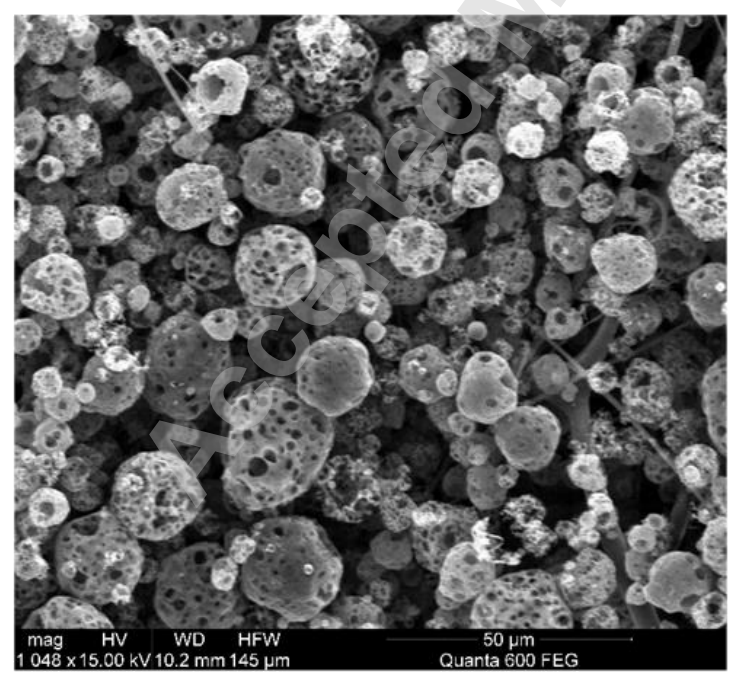

Case 3

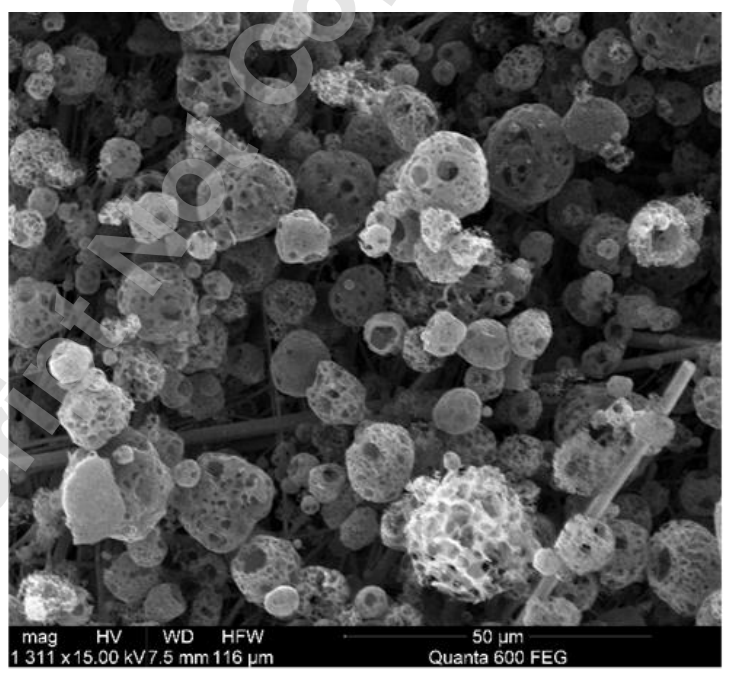

Case 2

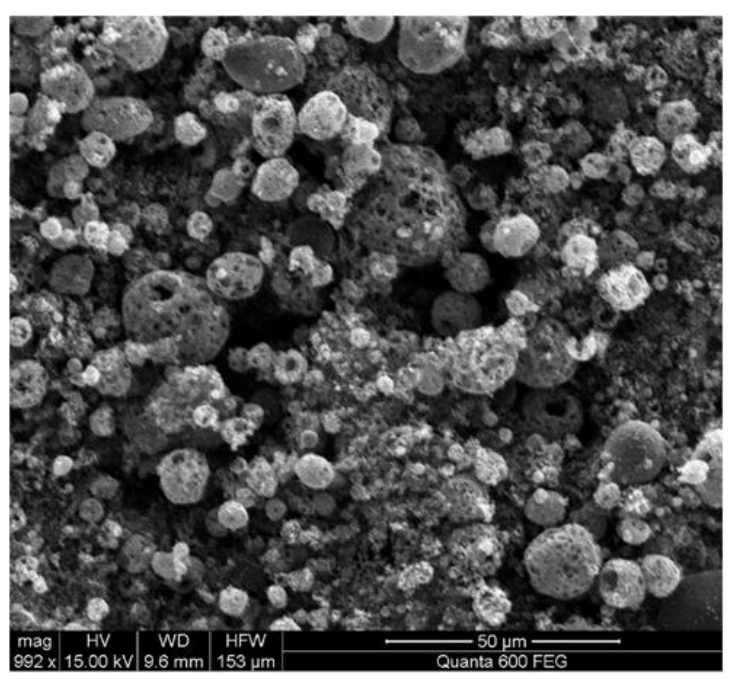

Case 4

Figure 8. SEM images of the PM collected on the micro-fiber filter paper. 
Table 4

Elemental composition of the PM

\begin{tabular}{ccccccccccc}
\hline & Sulfur & Nitrogen & Carbon & Hydrogen Oxygen & $\mathrm{K}$ & $\mathrm{Mg}$ & $\mathrm{Na}$ & $\mathrm{Ni}$ & $\mathrm{V}$ \\
\hline \multicolumn{1}{c}{ (mass \%) } \\
\hline Case1 & 5.58 & 1.02 & 80.16 & 0.44 & 5.73 & 1,077 & 220 & 16,302 & 1,638 & 4,917 \\
Case2 & 5.03 & 1.02 & 84.27 & 0.36 & 3.31 & 648 & 1,402 & 7,616 & 1,029 & 2,720 \\
Case3 & 4.62 & 0.93 & 79.50 & 0.57 & 7.12 & 589 & 1,030 & 9,189 & 1,272 & 3,939 \\
Case4 & 3.87 & 0.84 & 83.20 & 2.51 & 2.67 & 9.71 & 106.9 & 14.3 & 22.5 & 798 \\
\hline
\end{tabular}

The $\mathrm{pH}$ of the $\mathrm{PM}$ was also measured by dissolving $0.1 \mathrm{~g}$ of it in $30 \mathrm{ml}$ of deionized water and then exposing the solution to ultrasound, to increase the chemical activity in the solution. The $\mathrm{pH}$ of the solution was then measured and the values correspond to the sulfur content in the fuel. The measured $\mathrm{pH}$ values of the PM are reported in Figure 9.

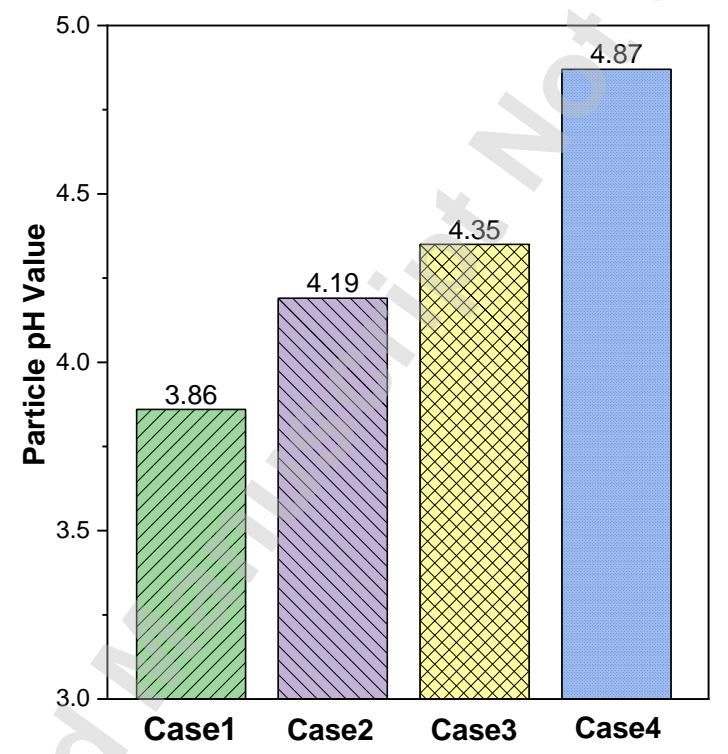

Figure 9. $\mathrm{pH}$ measurements of the PM.

\subsection{Carbon and sulfur balance}

Carbon and sulfur balance calculations were performed to assess the quantitative and qualitative distribution of these elements via gaseous and PM routes. For case 1 (pure HFO) calculations was performed using a basis of 1 minute and by measuring the composition of flue gas and PM emissions. The carbon and sulfur balance is presented in Figure $10.7 .7 \%$ of carbon and $15.6 \%$ of sulfur was lost due to measurement errors and due to particles adhering on the surface of the walls and burner. Approximately $98.7 \%$ of the carbon in the fuel goes into the flue gas as $\mathrm{CO}$ and $\mathrm{CO}_{2}$ emissions and 
the rest appears via PM emissions. Nearly $97.5 \%$ of sulfur translates into flue gas emissions namely $\mathrm{SO}_{2}$ and $\mathrm{SO}_{3}$ and the remaining $2.5 \%$ goes into the $\mathrm{PM}$. The flue gas $\mathrm{pH}$ calculations indicate that $5 \%$ of the total sulfur emissions are composed of $\mathrm{SO}_{3}$ and the rest $95 \%$ by $\mathrm{SO}_{2}$. Similarly, $99.7 \%$ of the gaseous carbon emissions appear as $\mathrm{CO}_{2}$ and $0.3 \%$ as $\mathrm{CO}$.

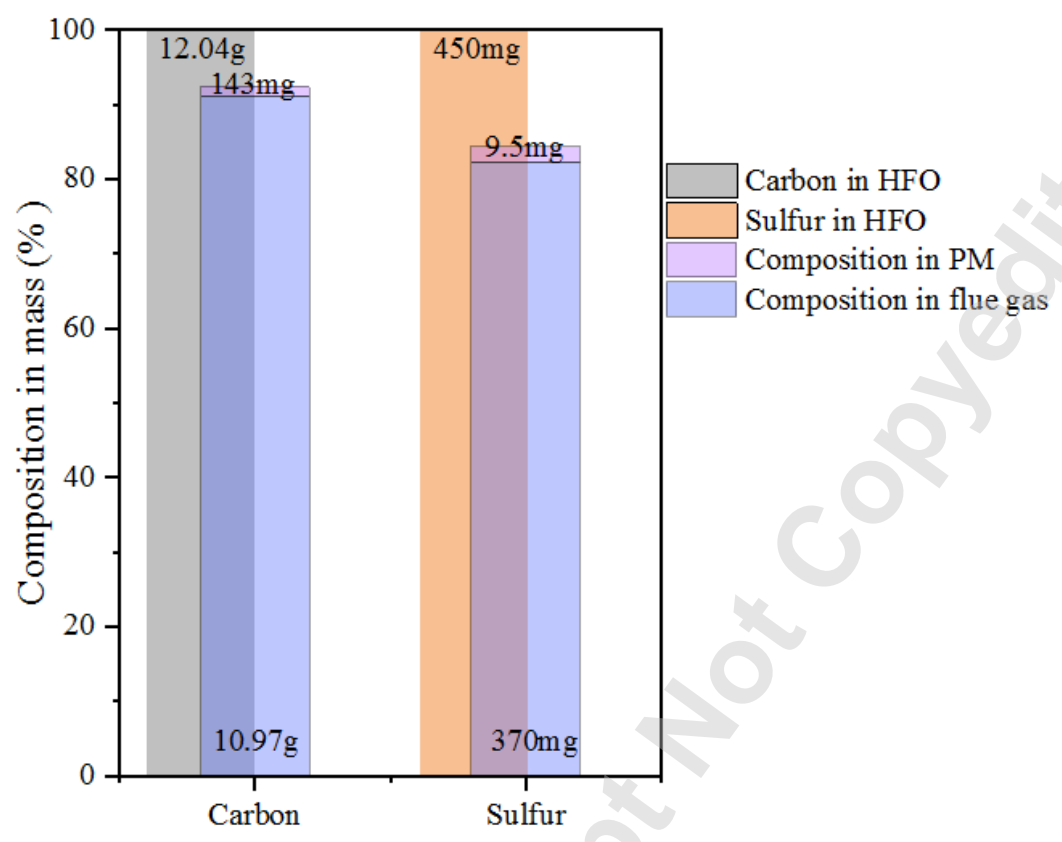

Figure 10. Carbon and sulfur balance: Emissions via gaseous and PM routes (Basis: 1 minute operation)

\section{Conclusion}

An experimental investigation of the effect of fuel sulfur content on combustion performance was performed using a high swirl, turbulent spray flame of HFO. Four test fuels containing 3.15, 2.80, 1.97 and $0.52 \%$ sulfur (by mass) was prepared by blending HFO with ultra-low sulfur diesel. Separately obtained pure asphaltenes were added to ensure that the asphaltenes content did not change. A maximum flame temperature of $1200^{\circ} \mathrm{C}$ was measured and sulfur content in the fuel did not have a major impact on the flame temperatures. $\mathrm{SO}_{2}$ emissions were directly proportional to the sulfur content in the fuel and increased from $48 \mathrm{ppm}$ to $620 \mathrm{ppm}$ when the sulfur in the fuel was increased from 0.52 to $3.15 \mathrm{wt} \%$. The flue gas $\mathrm{pH}$ measured for case 1 was the lowest at 3.1 whereas for case 5 it was highest at 4.23 due to the absence of sulfur in the fuel. The sulfur balance calculations show that $97.5 \%$ of sulfur in the fuel translates into flue gas emissions of which $\mathrm{SO}_{2}$ accounts for $95 \%$ and $\mathrm{SO}_{3}$ forms 
the remaining 5\%. The remaining sulfur (2.5\%) passes in to the PM emissions. Sulfur content did not have a major impact on the $\mathrm{NO}_{\mathrm{x}}$ emissions which remained around $100 \mathrm{ppm}$ for cases 1,2 and 3 due to similar flame temperature profiles. The morphology and size distribution of the PM did not change significantly with the sulfur content as the asphaltenes in the fuel samples were held in the same proportions.

\section{Acknowledgement}

Research reported in this publication was supported by Saudi Electric Company (SEC) and by competitive research funding from King Abdullah University of Science and Technology (KAUST). The authors acknowledge support from the Clean Combustion Research Center under the Future Fuels research program. This research used resources of the Core Labs of King Abdullah University of Science and Technology (KAUST).

\section{References}

[1] Abdul Jameel, A. G., Elbaz, A. M., Emwas, A.-H., Roberts, W. L., and Sarathy, S. M., 2016, "Calculation of Average Molecular Parameters, Functional Groups, and a Surrogate Molecule for Heavy Fuel Oils Using $1 \mathrm{H}$ and 13 C Nuclear Magnetic Resonance Spectroscopy,” Energy \& Fuels, 30(5), pp. 3894-3905.

[2] Elbaz, A. M., Gani, A., Hourani, N., Emwas, A.-H., Sarathy, S. M., and Roberts, W. L., 2015, "TG/DTG, FT-ICR Mass Spectrometry, and NMR Spectroscopy Study of Heavy Fuel Oil," Energy \& Fuels, 29(12), pp. 7825-7835.

[3] Nielsen, K. E., Dittmer, J., Malmendal, A., and Nielsen, N. C., 2008, "Quantitative Analysis of Constituents in Heavy Fuel Oil by $1 \mathrm{H}$ Nuclear Magnetic Resonance (NMR) Spectroscopy and Multivariate Data Analysis," Energy \& Fuels, 22(6), pp. 4070-4076.

[4] Abdul Jameel, A. G., Khateeb, A., Elbaz, A. M., Emwas, A.-H., Zhang, W., Roberts, W. L., and Sarathy, S. M., 2019, "Characterization of Deasphalted Heavy Fuel Oil Using APPI (+) FT-ICR Mass Spectrometry and NMR Spectroscopy,” Fuel, 253, pp. 950-963.

[5] Garaniya, V., McWilliam, D., Goldsworthy, L., and Ghiji, M., 2018, "Extensive Chemical Characterization of a Heavy Fuel Oil," Fuel, 227(April), pp. 67-78.

[6] Abdul Jameel, A. G., and Sarathy, S. M., 2018, "Lube Products: Molecular Characterization of Base Oils," Encyclopedia of Analytical Chemistry, John Wiley \& Sons, Ltd, Chichester, UK, pp. 1-14.

[7] Cheng, L.-H., Yeh, C.-F., Tsai, K.-C., Lee, P.-F., Tseng, T.-P., Huang, L.-J., Yeh, S.-H., Hsu, H.-T., Lin, C.-H., Lai, C.-H., Brimblecombe, P., and Chen, M.-J., 2019, "Effect of Pool Fire Scale of Heavy Fuel Oil on the Characteristics of PAH Emissions," Fuel, 235, pp. 933-943.

[8] Vaezi, M., Passandideh-Fard, M., Moghiman, M., and Charmchi, M., 2011, "Gasification of Heavy Fuel Oils: A Thermochemical Equilibrium Approach,” Fuel, 90(2), pp. 878-885.

[9] Abdul Jameel, A. G., Han, Y., Brignoli, O., Telalović, S., Elbaz, A. M., Im, H. G., Roberts, W. L., and Sarathy, S. M., 2017, "Heavy Fuel Oil Pyrolysis and Combustion: Kinetics and Evolved Gases Investigated by TGA-FTIR,” J. Anal. Appl. Pyrolysis, 127(August), pp. 183- 
195.

[10] Ma, H., Zhou, L., Lv, S., Chew, J. W., and Wang, Z., 2019, "Review on Reaction Mechanisms of Sulfur Species During Coal Combustion,” J. Energy Resour. Technol., 141(10), pp. 1-7.

[11] Borówka, G., Bytnar, K., Krzak, M., Walendziewski, J., and Zmuda, W. A., 2019, "Physicochemical Properties of Fuel Blends Composed of Heavy Fuel Oil and Tire-Derived Pyrolytic Oils," J. Energy Resour. Technol., 141(4), pp. 43-47.

[12] Zeng, X., Tan, Q., and Tan, Z., 2019, "Optimization of Combustion and Emission Characteristics of a Two-Stroke Marine Diesel Engine Based on Online Ultrasonic and Magnetization of Marine Heavy Fuel Oil," Combust. Sci. Technol., 191(7), pp. 1154-1167.

[13] Maurya, R. K., and Agarwal, A. K., 2015, "Experimental Investigations of Particulate Size and Number Distribution in an Ethanol and Methanol Fueled HCCI Engine," J. Energy Resour. Technol., 137(1), pp. 1-10.

[14] Lee Hong Liang, 2018, What You Need to Know: The 2020 IMO Fuel Sulphur Regulation.

[15] Halff, A., Younes, L., and Boersma, T., 2019, "The Likely Implications of the New IMO Standards on the Shipping Industry," Energy Policy, 126, pp. 277-286.

[16] Zis, T., and Psaraftis, H. N., 2017, "The Implications of the New Sulphur Limits on the European Ro-Ro Sector,” Transp. Res. Part D Transp. Environ., 52, pp. 185-201.

[17] Campuzano, F., Abdul Jameel, A. G., Zhang, W., Emwas, A.-H., Agudelo, A. F., Martínez, J. D., and Sarathy, S. M., 2020, "Fuel and Chemical Properties of Waste Tire Pyrolysis Oil Derived from a Continuous Twin-Auger Reactor," Energy \& Fuels, p. acs.energyfuels.0c02271.

[18] Abdul Jameel, A. G., Alkhateeb, A., Telalović, S., Elbaz, A. M., Roberts, W. L., and Sarathy, S. M., 2019, "Environmental Challenges and Opportunities in Marine Engine Heavy Fuel Oil Combustion," Proceedings of the Fourth International Conference in Ocean Engineering, Springer, pp. 1047-1055.

[19] Blatcher, D. J., and Eames, I., 2013, "Compliance of Royal Naval Ships with Nitrogen Oxide Emissions Legislation,” Mar. Pollut. Bull., 74(1), pp. 10-18.

[20] Javadli, R., and de Klerk, A., 2012, "Desulfurization of Heavy Oil," Appl. Petrochemical Res., 1(1-4), pp. 3-19.

[21] Khateeb, A. A., Elbaz, A. M., Guida, P., and Roberts, W. L., 2018, "Influence of Asphaltene Concentration on the Combustion of a Heavy Fuel Oil Droplet," Energy \& Fuels, 32(12), pp. 12981-12991.

[22] Villasenor, R., and Garcia, F., 1999, “An Experimental Study of the Effects of Asphaltenes on Heavy Fuel Oil Droplet Combustion," Fuel, 78(8), pp. 933-944.

[23] Elbaz, A. M., Khateeb, A. A., and Roberts, W. L., 2018, "PM from the Combustion of Heavy Fuel Oils," Energy, 152, pp. 455-465.

[24] Ikegami, M., Xu, G., Ikeda, K., Honma, S., Nagaishi, H., Dietrich, D. L., and Takeshita, Y.,

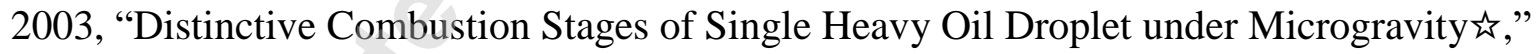
Fuel, 82(3), pp. 293-304.

[25] MARRONE, N. J., KENNEDY, I. M., and DRYER, F. L., 1984, "Coke Formation in the Combustion of Isolated Heavy Oil Droplets,” Combust. Sci. Technol., 36(3-4), pp. 149-170.

[26] Jiang, L., Elbaz, A. M., Guida, P., Al-Noman, S. M., AlGhamdi, I. A., Saxena, S., and Roberts, W. L., 2019, "Cenosphere Formation during Single-Droplet Combustion of Heavy Fuel Oil,” Energy \& Fuels, 33(2), pp. 1570-1581.

[27] Urban, D. L., and Dryer, F. L., 1991, "New Results on Coke Formation in the Combustion of Heavy-Fuel Droplets," Symp. Combust., 23(1), pp. 1437-1443.

[28] Moszkowicz, P., Witzel, L., and Claus, G., 1996, "Modelling of Very Fast Pyrolysis of Heavy Fuel Oil Droplets," Chem. Eng. Sci., 51(17), pp. 4075-4086.

[29] Azimi, A., Arabkhalaj, A., Shahsavan Markadeh, R., and Ghassemi, H., 2018, "Fully Transient Modeling of the Heavy Fuel Oil Droplets Evaporation," Fuel, 230, pp. 52-63.

[30] Fostiropoulos, S., Strotos, G., Nikolopoulos, N., and Gavaises, M., 2020, "Numerical Investigation of Heavy Fuel Oil Droplet Breakup Enhancement with Water Emulsions," Fuel, 278, p. 118381. 
[31] Stamoudis, N., Chryssakis, C., and Kaiktsis, L., 2014, "A Two-Component Heavy Fuel Oil Evaporation Model for CFD Studies in Marine Diesel Engines," Fuel, 115, pp. 145-153.

[32] Garaniya, V., and Goldsworthy, L., 2007, "Vaporization and Pyrolysis Modelling of a Single Droplet of Heavy Fuel Oil Using Continuous Thermodynamics,” ANZIAM J., 49, p. 116.

[33] Garaniya, V., and Goldsworthy, L., 2012, "Heavy Fuel Oil Combustion Modelling Using Continuous Thermodynamics," Mar. Eng., 47(6), pp. 871-877.

[34] Ben-Manosur, R., Ahmed, P., and Habib, M. A., 2015, "Simulation of Oxy-Fuel Combustion of Heavy Oil Fuel in a Model Furnace,” J. Energy Resour. Technol., 137(3), p. 04018059.

[35] Stefanitsis, D., Malgarinos, I., Strotos, G., Nikolopoulos, N., Kakaras, E., and Gavaises, M., 2017, "Numerical Investigation of the Aerodynamic Breakup of Diesel and Heavy Fuel Oil Droplets," Int. J. Heat Fluid Flow, 68, pp. 203-215.

[36] Costa, M., Costen, P., and Lockwood, F. C., 1991, "Combustion Measurements in a Heavy Fuel Oil-Fired Furnace,” Combust. Sci. Technol., 75(1-3), pp. 129-154.

[37] COSTA, M., COSTEN, P., and LOCKWOOD, F. C., 1991, "Detailed Measurements in a Heavy Fuel Oil-Fired Large-Scale Furnace," Combust. Sci. Technol., 77(1-3), pp. 1-26.

[38] Byrnes, M. A., Foumeny, E. A., Mahmud, T., Sharifah, A. S. A. K., Abbas, T., Costen, P. G., Hassan, S., and Lockwood, F. C., 1996, "Measurements and Predictions of Nitric Oxide and Particulates Emissions from Heavy Fuel Oil Spray Flames,” Symp. Combust., 26(2), pp. 2241-2250.

[39] Villasenor, R., and Escalera, R., 1998, "A Highly Radiative Combustion Chamber for Heavy Fuel Oil Combustion,” Int. J. Heat Mass Transf., 41(20), pp. 3087-3097.

[40] LIU, H., HE, K., HE, D., FU, L., ZHOU, Y., WALSH, M., and BLUMBERG, K., 2008, "Analysis of the Impacts of Fuel Sulfur on Vehicle Emissions in China," Fuel, 87(13-14), pp. 3147-3154.

[41] Saiyasitpanich, P., Lu, M., Keener, T. C., Liang, F., and Khang, S.-J., 2005, "The Effect of Diesel Fuel Sulfur Content on Particulate Matter Emissions for a Nonroad Diesel Generator," J. Air Waste Manage. Assoc., 55(7), pp. 993-998.

[42] Palani, R., AbdulGani, A., and Balasubramanian, N., 2017, "Treatment of Tannery Effluent Using a Rotating Disc Electrochemical Reactor," Water Environ. Res., 89(1), pp. 77-85.

[43] Abdul Jameel, A. G., Naser, N., Emwas, A.-H., Dooley, S., and Sarathy, S. M., 2016, "Predicting Fuel Ignition Quality Using 1 H NMR Spectroscopy and Multiple Linear Regression," Energy \& Fuels, 30(11), pp. 9819-9835.

[44] Feikema, D., Chen, R.-H., and Driscoll, J. F., 1990, "Enhancement of Flame Blowout Limits by the Use of Swirl," Combust. Flame, 80(2), pp. 183-195.

[45] CHEN, R.-H., DRISCOLL, J. F., KELLY, J., NAMAZIAN, M., and SCHEFER, R. W., 1990, "A Comparison of Bluff-Body and Swirl-Stabilized Flames," Combust. Sci. Technol., 71(46), pp. 197-217.

[46] Naser, N., Abdul Jameel, A. G., Emwas, A.-H., Singh, E., Chung, S. H., and Sarathy, S. M., 2019, "The Influence of Chemical Composition on Ignition Delay Times of Gasoline Fractions," Combust. Flame, 209, pp. 418-429.

[47] Lin, C., and Hsieh, M., 1996, "Emissions of Industrial Furnaces Burning Diesel Fuel Oils of Various Sulfur Contents with Nacl- Contained Atmospheric Air," J. Environ. Sci. Heal. . Part A Environ. Sci. Eng. Toxicol., 31(4), pp. 859-868.

[48] ALLOUIS, C., ROMANO, M., BERETTA, F., VIEGAS, L., and D’ALESSIO, A., 1998, "Particulate Formation from the Spray Combustion of Heavy Oil and Biofuel," Combust. Sci. Technol., 134(1-6), pp. 457-475.

[49] Maricq, M. M., Chase, R. E., Xu, N., and Laing, P. M., 2002, "The Effects of the Catalytic Converter and Fuel Sulfur Level on Motor Vehicle Particulate Matter Emissions: Light Duty Diesel Vehicles,” Environ. Sci. Technol., 36(2), pp. 283-289.

[50] Liu, J., Liu, H., Guo, X., Yao, H., and Chen, J., 2018, "Nitrogen and Sulfur Behavior During Oxy-Fuel Combustion and Its Retention," Oxy-Fuel Combust., pp. 87-127.

[51] Tang, H., Xu, M., Hu, H., Yang, F., Yang, Y., Liu, H., Li, X., and Yao, H., 2018, "In-Situ Removal of Sulfur from High Sulfur Solid Waste during Molten Salt Pyrolysis," Fuel, 231, 
pp. 489-494.

[52] Li, P., Wang, F., Mi, J., Dally, B. B., Mei, Z., Zhang, J., and Parente, A., 2014, "Mechanisms of NO Formation in MILD Combustion of $\mathrm{CH} 4$ /H 2 Fuel Blends," Int. J. Hydrogen Energy, 39(33), pp. 19187-19203.

[53] Koehl, W. J., Benson, J. D., Burns, V. R., Gorse, R. A., Hochhauser, A. M., Knepper, J. C., Leppard, W. R., Painter, L. J., Rapp, L. A., Reuter, R. M., and Rutherford, J. A., 1993, "Effects of Gasoline Sulfur Level on Exhaust Mass and Speciated Emissions: The Question of Linearity - Auto/Oil Air Quality Improvement Program," pp. 3-5.

[54] Anacleto, P. M., Fernandes, E. C., Heitor, M. V., and Shtork, S. I., 2003, "Swirl Flow Structure and Flame Characteristics in a Model Lean Premixed Combustor," Combust. Sci. Technol., 175(8), pp. 1369-1388.

[55] Gonul, H. I., and Bilen, M., 2020, "Modeling Absorbers in WFGD System and Prediction of SO2 Removal Rate Based on Size Parameters," J. Energy Resour. Technol., 142(8).

[56] Clayton, R. M., and Back, L. H., 1989, "Physical and Chemical Characteristics of Cenospheres From the Combustion of Heavy Fuel Oil,” J. Eng. Gas Turbines Power, 111(4), pp. 679-684.

[57] Winnes, H., and Fridell, E., 2010, "Emissions of NOX and Particles from Manoeuvring Ships,” Transp. Res. Part D Transp. Environ., 15(4), pp. 204-211.

[58] Contini, D., Gambaro, A., Donateo, A., Cescon, P., Cesari, D., Merico, E., Belosi, F., and Citron, M., 2015, "Inter-Annual Trend of the Primary Contribution of Ship Emissions to PM 2.5 Concentrations in Venice (Italy): Efficiency of Emissions Mitigation Strategies,” Atmos. Environ., 102, pp. 183-190.

[59] Miller, C. A., Linak, W. P., King, C., and Wendt, J. O. L., 1998, "Fine Particle Emissions from Heavy Fuel Oil Combustion in a Firetube Package Boiler," Combust. Sci. Technol., 134(1-6), pp. 477-502.

[60] Groenzin, H., and Mullins, O. C., 2007, Asphaltenes, Heavy Oils, and Petroleomics, Springer New York, New York, NY.

[61] Goldstein, H. L., and Siegmund, C. W., 1976, "Influence of Heavy Fuel Oil Composition and Boiler Combustion Conditions on Particulate Emissions," Environ. Sci. Technol., 10(12), pp. 1109-1114.

[62] Fang, W., Kittelson, D. B., and Northrop, W. F., 2017, "Dilution Sensitivity of Particulate Matter Emissions From Reactivity-Controlled Compression Ignition Combustion,” J. Energy Resour. Technol., 139(3), pp. 1-6. 